\title{
Migration controls and counter-terrorism in Europe: a discussion of challenges and policies
}

\author{
Ziyad Abdulqadir 1 A \\ A University of Warsaw, Poland
}

Received: February 25, 2021 | Revised: April 11, 2021 | Accepted: April 30, 2021

DOI: $10.33445 /$ sds.2021.11.2.3

\begin{abstract}
This paper explores the European suspicion against the migrants and analyses the European security concerns regarding terrorist attacks. The paper shows that Europeans' wrong perception about migrants has been created by homogenizing the category of migrants as well as politicizing the issue of migrants for electoral maneuvering. The suspicion has been grown after the 9/11 terrorist attack on America. Islamic radical organization Al-Qaeda perpetrated this attack to achieve its political agenda. This attack gave legitimacy to America and Europe to suspect everybody who is coming into their area. The studies on linking migration with terrorism show scanty evidence, but scholars have biased opinions on this. The paper explores all these issues.
\end{abstract}

Key words: terrorism, counterterrorism, migration, European culture, threats.

\section{Introduction}

Terrorism has been a real challenge for many countries of the world in recent years. Terrorist networks are now working globally. Terrorism is defined in the Oxford Dictionary as the unlawful use of violence and intimidation, especially against civilians, in the pursuit of political aims (Teichman, 1989, p. 505-517). According to Hoffman 1998 terrorism is the deliberate creation and exploitation of fear through violence or the threat of violence in the pursuit of political change (Hoffman, 1998, p.43). Terrorism is the intentional use of or threat to use violence against civilians or civilian targets. According to Boaz Gano, terrorist as violence or threat of violence perpetrated by private individuals or small groups from the hegemonic strata against civilian people or members of government to achieve a political goal. Therefore, a terrorist is an individual who carries out or threatens to carry out acts of terror (Ganor, 1998). Whether or not that individual acts on one's own behalf or is hired by someone else to perform a terrorist attack is not important given that definition. It can generally be said that very different, often selfcontradictory motives stand behind harming or killing others (be it, direct enemies or innocent victims). Inter alia, these motives include monetary gain, a gain of group principle, and gain of personal principle. Although these motives may seem contradictory in their nature, they are often combined when it comes to a particular attack, and thus are to be regarded inseparably.

\section{Results and discussion}

\section{Terrorism is an old Practice}

Although attention to the subject of terrorism has increased sharply in recent years, but it is not a new phenomenon, for decades terrorists have carried attacks against noncombatant targets causing destruction by means of vicious assaults. While the objectives and modus operandi have changed, there is no

\footnotetext{
${ }^{1}$ Corresponding author: Doctoral Candidate, Faculty of Psychology, e-mail: abdulqadir.ziyad@psych.uw.edu.pl, ORCID: 0000-0002-0558-7002
} 
reason to believe that terrorism will completely cease to exist in the near future. The vicious cycle has thus far not been broken. Some argue that the key to successfully dealing with terrorism lies in understanding its root and trigger causes. Others contend that it is equally important to consider factors of decline. After the significant event 11th of September in the United States, the West made it its goal to address the problem of terrorism from its roots, but to understand the roots of terrorism, it is important to understand the causes of extremism and understand the definition of extremism (Casper Vriese, 2016, p.9).

1) Extremism

Extremism is a kind of ideology that stresses too much on the religious aspect of our daily lives. Religious extremists follow an extreme ideology and work to sustain that ideology into larger people by radicalizing them by any means. The 9/11 attack was perpetrated by Islamic religious extremists. Al-Qaeda a militant group working in Afghanistan attacked the American twin tower in 2001 and killed 2,977 people by hijacking and colliding two American aeroplanes full of passengers. Wiktorowicz, 2005 provides a four-stage framework of extremism in which the grievance of some person provides a platform to form a radical belief system based on violence. When a person becomes a member of that grievance group then the person has no choice other than commit violence on behalf of the group. This radical ideology creates a vicious cycle of mass murders, encounters and suppression.

2) Migration and Extremism

World Migration Report 2018 links migration with the rising threat of violent extremism and terrorism (World Migration Report, 2018). The report also emphasizes that we have to make a distinction between migrants, asylums seekers and refugees. These three categories entail different backgrounds of extremism and their immigration status. This paper also talks about internal migrants and internally displaced persons (IDPs) and show that data related to their extremism is scanty (World Migration Report, 2018, p.2.). While identifying Foreign Terrorist Fighters (FTFs) paper points out towards newly arrived asylum seekers and concludes that the conflicting countries can give birth to FTFs. The descendants of migrants of these countries could also be radicalized. Some countries are the breeding ground for terrorism. The report suggests that better migration management can tackle this problem (World Migration Report, 2018). Global Terrorism Index 2016 showed that five countries became the hub of most terrorist activities. These countries are Iraq, Afghanistan, Nigeria, Pakistan and Syria (Economics and Peace, 2016). Thus, migration is not the cause of terrorism as these countries are not giving refuge to the migrants.

Religious extremism, terrorism leads to the migration of people to developed countries just because of these cruel consequences of human security moreover in the third world. Most people are experiencing extreme poverty. The incident of 9/11 raised a serious question of development and security in the Middle-East and South Asia. (Bharti, 2020, p. 280, 282). US war against terror moreover increased extremism and terrorism in the Middle East especially in South Asia (Afghanistan and Pakistan) which become a major consequence of the migration of people towards Europe.

\section{Drivers of Extremism}

USAID report of 2011 points out push and pull factors of violent extremism. According to the report high level of Social marginalization and fragmentation, poorly governed or ungoverned areas, government repression and human rights violations and endemic corruption, elite impunity and cultural threat perceptions are the push factors of violent extremism (USAID, 2011, p.3). The pull factors of violent extremism are access to a material resource, access to social status, respect from peers, a sense of belonging, a sense of adventure, self - esteem or personal empowerment, a sense of making history and the prospects of achieving glory and fame (USAID, 2011, p.4).

3) Migration and Terrorism

Authors find no significant likelihood of terrorist activity to increase for migrants coming from Muslim-majority countries and countries with intensive terrorist activity. Evidence from 170 countries, from 1990 to 2015, suggests that 
an increase in the share of immigrants is not correlated with higher rates of terrorism (USAID, 2011, p.4). Researchers also show that the linking migration and terrorism has a political ramification as conservatives in Europe, which are increasing especially in Central Europe. Though, the rise of the far-right-wing government in Hungary and Poland leads to this perception against migration moreover it's a political card to pull European Union's (EU) migration policy away. These two countries have never appreciated the EU's migration policy.

Increasing Insecurity in Europe due to Migration

In recent times terrorist attacks and threats have risen over the whole world and particularly in Europe. Since the end of World War II, the European continent has not faced a situation that could even in the slightest resemble today's concerns in the field of security threats. European Union region, famous for its strategy of peaceful co-existence, and to the extent of the threat of European Union region, "Schengen", Pax Europaea, has shown a degree of vulnerability in view of the wave of refugee migration. Some argue that the refugee crisis has highlighted the contrast between the Union's approach in the field of security on the one hand, and the crisis of illegal immigrants on the other (Hussaein, 2016).

The displacement of refugees represents a crisis of major proportions that may contribute to intrastate instability (Salehyan, \& Gleditsch, p. 335-366). Statistics show that many Europeans are convinced that recent waves of immigration to Europe will impact their safety and increase the terrorist threat this tendency is concerned in an opinion survey conducted by "Pew" Center for American Research. In addition, a number of Europeans feel threatened economically, claiming that the refugees will take jobs and hold their countries many financial and economic burdens. Where reached a wary proportion of the refugees are high recorded in Hungary (76\%) and Poland (71\%). It is worth noting that the two countries have accepted a relatively small number of immigrants over the last few years, and their governments have adopted a restrictive policy toward refugees. The third-place the Netherlands (61\%) and Germany with the same percentage which received the largest number of immigrants and the citizens have expressed these concerns, while the ratio was $60 \%$ in Italy and $52 \%$ in Britain (Wike, Stokes and Simmons, 2016).

In general, Europeans perceive a clear link between the "problem of the asylum seekers" and the threat of terrorism. The matters remain open and result in more terrorist attacks involving innocent people. Meanwhile, the solutions remain available and appropriate measures have to be taken in order to minimize the threat and risk it, as well as to implementation intensify the campaign to confront terrorism with hard work on his lack of support in other areas, on the grounds that the confrontation with terrorism not be localized (Harb, 2016).

\section{Collective Counter-Terrorism Policies in Europe}

Considering the fears, risks and other side effects involved, it is no wonder that combatting terrorism has become a collective responsibility, both regionally and globally. In this regard, several international laws, decisions and agreements have been formulated or signed to tackle the problem. In addition, organizations have been established, conferences and annual meetings have been held. However, the problem cannot be tackled solely via the use of military force. Such measures alone will not decrease the threat nor put an end to the terrorist attacks. It is particularly important to realize that nowadays when the European population perceives the threat of terrorism as something real and "within their reach".

\section{Terrorist Attacks Increased}

Taking a retrospective look, one may get an impression that terrorism in Europe has reached its peak in the past, more precisely from the 1970s and 1980s were Europe's most violent decades in terms of terrorism (Florence Gaub, 2017), and since the seventies of the twentiethcentury Terrorism in Europe has killed 11,288 people in 18,811 attacks, which tracks more than 170,000 foreign and domestic incidents worldwide (Regional Cooperation Council-RCC, 
2016). However, as the current data shows, the terrorist threat intensified again and was not percentage in the seventies and eighties scattered strongly as today states that the rise in the perceived threat of terrorism is incompatible with the scale of actual terrorist attacks.

If we look at it from an international perspective, the number of actual terrorist attacks in Europe, compared to the rest of the world, is still relatively low. It can be proven with the data from the Database of International Terrorism of the University of Maryland - START Center, referring to the years 2001 and 2014 respectively. According to that data, the rate of increase in terrorist activity in Europe over these 14 years is only 0.3 per cent, which is not a lot compared to others in the world's total (GTD Global terrorism database, 2016). While in the last two years in Europe 443 victims were killed in 18 deadly terror attacks, according to the British edition of the Daily Mail published a map which shows the advanced in Europe in the years 2014 four people were killed in a deadly attack in Brussels, in 2015 a staggering 267 people were slain in atrocities across the continent and so far, in 2016, 172 have died in terrifying attacks (Sarah Dean, 2016). This is a clear signal that the terrorist activity and threat in Europe has somehow increased, which in turn affects the opinion of European citizens towards immigrants and raises the proportion of their fears and concerns over the security of their lives.

A large proportion of immigrants that came from society completely different from Europe in terms of culture has led to the creation of a large gap. The factors around this gap include the lack of adaptation and harmony and the lack of understanding between these different cultures which have not been able to coherence with each other. Various problems may arise from these and some other factors, such as violent actions, latent xenophobia (Antúnez, 2019), and an increase in perceived terrorist threat as well.

The negative consequences of illegal immigration on the one hand and the increased terrorist threat on the other hand may lead to the further spread of citizens' concerns, sense of the lack of security, feeling unsure of their lives, growing aversion and hatred towards foreigners and multinational groups and different religions. All of this in turn leads to the emergence of internal conflicts and a sociopolitical crisis. This will give a good ground for the development of racist and nationalist tendencies and also seem an appropriate opportunity for groups and extreme right-wing parties to exploit this situation for their political interests, regardless of the seriousness of the terrorist attacks are moving towards more.

\section{Negative Perception of Europe towards Refugees}

Although the public perception towards the refugees in Western countries are negative that they believe that letting these individuals enter one's country increases that country's risk of terror attacks. Consequently, according to the research which investigated and analyzed the relationship between refugees' extremism and emigration intentions of five hundred Syrian refugees were surveyed in Jordan and Lebanon. This was also explored the relationships between willingness to immigrate and extreme ideological beliefs, as well as findings obtained that the refugees who expressed the intention to immigrate to the West were less ideologically extreme and less willing to sacrifice for religion, and refugees who want to move to the West have expressed more positive attitudes toward Western countries (Kruglanski, Jaśko, Molinario and Webber, 2018, p. 9-10). As shown in Table 1 in the research on migration-terrorism nexus is rather scarce.

Most of the studies were done in the last decade. The findings of analyzed empirical literature are mixed. Likewise, "there is no uniquely view that immigration increases or induces terrorism. Immigration -terrorism nexus is analyzed in a framework of three research areas - immigration policies (asylum), attitudes towards migrants and migration and migration itself. The bulk of the research is quantitative in nature. Applied methodology ranges from panel data analysis, negative binomial model to difference-in-differences model and OLS (spatial)". The qualitative approach encompasses the qualitative content analysis 
and metaphor identification procedure (Daniel Dragičević, 2019, p.8).

\section{Safeguarding the Borders and European Policy}

European authorities are very conscious about their border security (Sarah Leonard, 2015). Making borderland safe became normal after the 9/11 terrorist attack on America (United Nations, 2001). The European Union Solidarity Fund was created to finance the civil protection operations (Eur-Lex). This also induced European Union to insert "the solidarity Clause" in the Treaty on Functioning of the European Union. This clause was implemented as anticipated following the terrorist attacks in Madrid in March 2004. There are some of the European cities also experienced terrorist attacks as well as 9/11 already took place and both changed security dimension in EU (Bharti, 2020, p. 290).

Article 222 - The Functioning of European Union: the solidarity clause (Eur-Lex, 2016).

1. The Union and its Member States shall act jointly in a spirit of solidarity if a Member State is the object of a terrorist attack or the victim of a natural or man-made disaster. The Union shall mobilize all the instruments at its disposal, including the military resources made available by the Member States, to:

(a) prevent the terrorist threat in the territory of the Member States;

- protect democratic institutions and the civilian population from any terrorist attack;

- assist a Member State in its territory, at the re-quest of its political authorities, in the event of a terrorist attack;

(b) assist a Member State in its territory, at the re-quest of its political authorities, in the event of a natural or man-made disaster.

2. Should a Member State be the object of a terrorist attack or the victim of a natural or manmade disaster, the other Member States shall assist it at the request of its political authorities. To that end, the Member States shall coordinate between themselves in the Council.

3. The arrangements for the implementation by the Union of the solidarity clause shall be defined by a decision adopted by the Council acting on a joint proposal by the Commission and the High Representative of the Union for Foreign Affairs and Security Policy. The Council shall act in accordance with Article 31(1) of the Treaty on European Union where this decision has defence implications. The European Parliament shall be informed.

For the purposes of this paragraph and without prejudice to Article 240, the Council shall be assisted by the Political and Security Committee with the support of the structures developed in the context of the common security and defence policy and by the Committee referred to in Article 71; the two committees shall, if necessary, submit joint opinions.

4. The European Council shall regularly assess the threats facing the Union in order to enable the Union and its Member States to take effective action.

Thus, we can see that the $9 / 11$ attack and Madrid attack of 2004 provided leverage to European Union to curb the countries law regarding migration and asylum. This made the EU as NATO as far as with the terrorist attacks. The EU has specific laws concerning terrorist organizations, their members and operations. These include one on a joint EU list of persons whose terrorist assets must be confiscated. In 2015, the EU presented a new Internal Security Strategy to step up the EU's response to terrorism. EU also assessed the main issues to be tackled after Stockholm Programme on EU priorities for the area of justice, freedom and security came to an end in December 2014. The EU's Internal Security Fund (2014-2020) (ISFPolice) includes finance for actions relating to fighting serious and organized crime, including terrorism (European Commission).

\section{Disablers of Terrorism}

Choi, (2018) points out that countries with more restrictive immigration policies i.e., states with reduced immigration based on skill or wealth diminish the risk of terrorism. Similarly, Bohmelt \& Bove, (2019) research confirms that terrorism diffuses via migration but only in target countries with extremely lax regulations and control mechanisms.

Corrective Measures to Change the False Perception 
Therefore, to counter-terrorism on one hand and reduce fears of a sense of European citizens, on the other hand, the following steps may be worth taking:

1. Conduct studies on the prisoners who convicted of terrorism prisoners in Europe, to know the reasons and motives of their actions because any acts of behavior are not without reason and special defended, to some extent this is not exposed by the authority.

2. Should find out the equation of cognitive, actions and interests of terrorism. The knowledge of the cognitive level of the terrorist it is essential because the human while acting, that this act by his knowledge, that is mean the quantitative and qualitative of the cognitive ready by this human if who terrorist or any other normal person, that are mean the quantitative and qualitative of the cognitive ready by this human if who terrorist or any other normal person, from other points the knowledge and taking into consideration the interests of terrorist is an important case because human being move want to achieve their interests when knowing all of it treating with the terrorist is easier from do not knowing anything from them and want to against or react them (Abdullah, 2010).

3. Make the process of assimilation for immigrants, this is on or decreasing steps to terrorism, they mix the refugees with their society and give them chance to participate in social affairs, opening workshop, and different courses in order to bring habits of European society and reflect in their personal life.

4. They have to treat them in justice and humanity in order to change their stereotype towards Europeans.

5. Making a special program for whom are not ensure that they are terrorist and make them social or after we ensure that they are from a group of terrorists, must deport them to their country.

\section{Conclusions}

Those things to do give simplicity to situations associated to react terror and increased fear and attack even the phenomenon of terror is the theme of ideology, economy, society, psychology etc, and will be doing a step in every level in order to react and to ensure the security and safety. There is a problem regarding migration controls policy and perception of European's right parties they do not want let especially Muslim migration towards Europe. However, there is a need for re-construction of developing countries where development policy can lead to address above challenges that leads to fragility violent extremism and conflict especially in the Middle East and South Asia. (Bharti, 2020, 73-74). Though, the EU should focus its development policy seriously on migration controls and counter-terrorism first in Middle-East where religious extremism is a serious challenge to not only Europe also the world.

\section{References}

Antúnez, Juan Carlos, (October 21, 2019), Refugees and Terrorism: The Real Threat, Políticas De Seguridad, Global Strategy, Universidad De Granad.

Bharti, S. S. (2020). Development Economics and Re-construction of Developing Countries: Reflections and Insights. Journal of Scientific Papers "Social Development and Security", 10(4), 69-77. DOI: 10.33445/sds.2020.10.4.6

Bharti, S. S. (2020). Strengthening the Development Partnership between the EU and South Asia: A Contemporary Analysis. Slovak Journal of Political Sciences, 20(2), 278-298. DOI: 10.34135/sjps.200205

Consolidated Version of Treaty on the Functioning of the European Union, https://eur-lex.europa.eu/legalcontent/EN/TXT/PDF/?uri=OJ:C:2016:202:FU LL\&from $=E N$

Dean, Sarah, Continent of fear, DailyMail online, 27 July 2016, Available from: http://www.dailymail.com 
Dragičević, Daniel, Is there any Correlation between Terrorism and Immigration? Evidence From Eu Countries, Journal of Business Paradigms, Vol. 4, No 2, 2019, pp. 421.

European Union, Consolidated Version of Treaty on the Functioning of the European Union, Available from: https://eurlex.europa.eu/legalcontent/EN/TXT/PDF/?uri=OJ:C:2016:202:FU LL\&from $=E N$

Ganor, Boaz. 1998. "Defining Terrorism: Is One Man's Terrorist Another Man's Freedom Fighter?" International Policy Institute for Counter-Terrorism, Herzlia, Israel. Sept. 24. Accessed at: http://www.ict.org.il/.

Gaub, Florence, (8 March 2017) Trends in terrorism, European Union Institute for Security Studies (EUISS), EU Institute for Security Studies | QN-AL-17-004-2A-N | ISBN 978-92-9198-511-1 | ISSN 2315-1129 | DOI: $10.2815 / 66788$.

Global Terrorism Index 2016, Available from: http://economicsandpeace.org/wpcontent/uploads/2016/11/Global-TerrorismIndex-2016.2.

GTD Global terrorism database, Codebook: Inclusion Criteria and Variables, START A Center of Excellence of the U.S. Department of Homeland Security, University of Maryland, College Park, MD 20740, USA 301.405.6600, June 2016.

Harb, Dr Hani, Reconnaissance: Many Europeans are afraid of the terror by refugees, Abwab, the first European website written in Arabic, by refugees and for refugees. Unit 5 Cavendish House, 369-391 Burnt Oak Broadway, Edgware HA8 5AW, Greater London, United Kingdom, http://www.abwab.eu/contact-us/ July 12, 2016.

Hoffman, Bruce. 1998. Inside Terrorism. Columbia University.

https://www.rcc.int/swp/news/55/46-years-ofterrorist-attacks-in-europe-visualized

Hussaein, Sammur Obsessed with the security of Europe an open confrontation with terrorism, Al-Manar net, Lebanon, 29 March

2016, Available from:

http://english.almanar.com.lb/

Karim Zirak Abdullah, Terrorism in the mirror of the sociology of knowledge, master thesis, Lugansk 2010.

Kruglanski, Arie, and Katarzyna Jaśko, Erica Molinario, David Webber. (July 2018), Potential for radicalization amongst Syrian refugees in Jordan and Lebanon: Risks, factors, and implications. Report to the Office of University Programs, Science and Technology Directorate, U.S. Department of Homeland Security. College Park, MD: START p. 9-10.

Leonard, Sarah, Border Controls as a Dimension of the European Union's Counter-Terrorism Policy: A Critical Assessment, Available from: https://www.tandfonline.com/doi/abs/10.1 080/02684527.2014.988447

Poushter, Jacob, September 16, 2016, European opinions of the refugee crisis in 5 charts, https://www. pewresearch.org/facttank/2016/09/16/european-opinions-of-therefugee-crisis-in-5-charts.

Regional Cooperation Council (RCC), Security Web Portal (SWP), IISG Integrative Internal Security Governance, 46 years of terrorist attacks in Europe, visualized, 06.08.2018

Salehyan, I., \& Gleditsch, K. S. (2006). Refugees and the spread of civil war. International Organization, 335-366.

Teichman, J. (1989). How to define terrorism. Philosophy, 64(250), 505-517.

Trump D.J. (2017) Executive order 13769: protecting the nation from foreign terrorist entry into the United States. Federal Register 82, 8977-8982 .

United Nations Security Council Resolution 1373, S/RES/1373 (2001), 28 September 2001

USAID, The Development Response to Violent Extremism and Insurgency.

Vriese, Casper (November 2016) Facing the root causes of terrorism, The Sociology of Development and Change Group, Wageningen University, Supervisor: dr.ir. G van der Haar 950413917050.

Wike, Richard, Bruce Stokes and Katie Simmons, 
Global Attitudes \& Trends, Pew Research Center, 1615 L Street, NW, Suite 800, Washington, DC 20036, July 11, 2016, Available from: www.pewglobal.org.

Wiktorowicz, Quintan Radical Islam Rising: Muslim Extremism in the West.

World Migration Report 2018, Chapter 9, Available https://onlinelibrary.wiley.com/doi/pdf/10.1 002/wom3.9.

Wright J.D. and Esses V.M. (2019) it's security, stupid! Voters' perceptions of immigrants as a security risk predicted support for Donald Trump in the 2016 US presidential election. Journal of Applied Social Psychology 49, 3649. 